\title{
Assessment of Different Modelling Studies on the Spatial Hydrological Processes in an Arid Alpine Catchment
}

\author{
Jiao Liu ${ }^{1,2,3} \cdot$ Tie Liu ${ }^{1} \cdot$ Anming Bao ${ }^{1}$. \\ Philippe De Maeyer $^{3} \cdot$ Xianwei Feng $^{1} \cdot$ Scott N. Miller $^{4}$. \\ Xi Chen ${ }^{1}$
}

Received: 6 March 2015 / Accepted: 26 January 2016 /

Published online: 12 February 2016

(C) The Author(s) 2016. This article is published with open access at Springerlink.com

\begin{abstract}
To assess the model description of spatial hydrological processes in the arid alpine catchment, SWAT and MIKE SHE were jointly applied in Yarkant River basin located in northwest China. Not only the simulated daily discharges at the outlet station but also spatiotemporal distributions of runoff, snowmelt and evapotranspiration were analyzed contrastively regarding modules' structure and algorithm. The simulation results suggested both models have their own strengths for particular hydrological processes. For the stream runoff simulation, the significant contributions of lateral interflow flow were only reflected in SWAT with a proportion of $41.4 \%$, while MIKE SHE simulated a more realistic distribution of base flow from groundwater with a proportion of $21.3 \%$. In snowmelt calculation, SWAT takes account of more available factors and got better correlations between snowmelt and runoff in temporal distribution, however, MIKE SHE presented clearer spatial distribution of snowpack because of fully distributed structure. In the aspect of water balance, less water was evaporated because of limitation of soil evaporation and less spatially distributed approach in SWAT, on another hand, the spatial distribution of actual evapotranspiration $\left(\mathrm{ET}_{\mathrm{a}}\right)$ in MIKE SHE clearly expressed influence of land use. Whether SWAT or MIKE SHE, without multiple calibrations, the model's limitation might bring in some biased opinions of hydrological processes in a catchment scale. The complementary study of combined results from multiple models could
\end{abstract}

Tie Liu

liutie@ms.xjb.ac.cn

Jiao Liu

jiao.liu@ugent.be

1 State Key Laboratory of Desert and Oasis Ecology, Xinjiang Institute of Ecology and Geography, Chinese Academy of Sciences, 818 Beijing South Road, Urumqi, Xinjiang 830011, China

2 University of Chinese Academy of Sciences, Peking 100049, China

3 Department of Geography, Gent University, Ghent 9000, Belgium

4 Department of Ecosystem Science and Management, University of Wyoming, Laramie 82071, USA 
have a better understanding of overall hydrological processes in arid and scarce gauges alpine region.

Keywords Hydrological processes · Joint application · Water component distribution · Modules' structure and algorithm . Yarkant River basin

\section{Introduction}

Hydrologic models are essential to understand hydrological processes, for quantifying interactions among natural physical factors (Boorman and Sefton 1997) and assessing management strategies (Loukas et al. 2007). However, even with same input data, different hydrological models that are applied in same study basin might generate dissimilar simulation results (Jiang et al. 2007; Maurer et al. 2010; Shi et al. 2011). Even the correct global trend can be attained together, but otherness was still existed in the processes and spatial interactions (Ferrant et al. 2011). So the model selection becomes a priority for a successful hydrology studies in special region (Maurer et al. 2010; Vansteenkiste et al. 2013).

In practice, model selection is limited by common practice of modellers; it is rare that an objective model selection approach is authentic (Najafi et al. 2011; Nasr et al. 2007), which causes trouble for water resources decision makers in continuing water resource management (Wood 2004). In the phase2 of the Distributed Model Intercomparison Project (DMIP2) (Smith et al. 2012, 2013), several distributed models was mixed compared to lumped benchmark, results indicated there was none single model can perform best in all cases. DANUBIA component (Barthel et al. 2012) comprised of 17 model components and discussed the integrated simulation of global change influence on agriculture and groundwater. Najafi et al. (2011) farther suggested that joint application of different models would be significant for water resource management after using four hydrologic models in Tualatin River basin. These previous studies emphasized the importance of model selection and combined application of multiple models, however, there is little focus on the model performance of spatial hydrological processes, but only the discharges, and did not give detail interpretations of output deviations among different models.

The semi-distributed SWAT (Arnold et al. 1998) and fully distributed European Hydrological System (MIKE SHE) (Abbott et al. 1986), are two physically based hydrological models, their simulation including all the water balance components of a watershed. These two models have many good applications for hydrology studies (Kaini et al. 2012; Najafi et al. 2011; Thampi et al. 2010; Thompson et al. 2004). Fontaine et al. (2002) incorporated a modified snowfall-snowmelt routine through elevation bands in SWAT. MIKE SHE is a deterministic hydrological model whose input data and parameters are independent in each grid, and spatial heterogeneities of study basin can be described detailedly. Therefore, both SWAT and MIKE SHE are capable to be applied in alpine basin (Ahl et al. 2008; Debele et al. 2009; Liu et al. 2011, 2012; Rahman et al. 2012; Smerdon et al. 2009).

Since SWAT and MIKE SHE can fulfil their modelling tasks independently, there are only small numbers of studies intended to quantify the differences between two of them. Furthermore, most attentions focused on the goodness of fit indices for the modelled discharges at outlet (El-Nasr et al. 2005; Golmohammadi et al. 2014). While, the calibration solely at basin outlets alone and ignoring other hydrological components was not able to greatly improve model's reliability and accuracy (Smith et al. 2013). 
Mountainous watersheds, headstream of most river basins in arid region, play an important role in water resource management for the downstream region (Rahman et al. 2012). Tarim River basin, which is the longest inland river in world, is located in Xinjiang Province in northwest China. The limited water resources have severely affected sustainable development of this region and caused a vulnerable ecological environment (Chen et al. 2006; Liu et al. 2011). Yarkant River is the largest tributaries and primary water sources of Tarim River. Since most studies of Yarkant River basin have focused on the single effect of snow and glacier melt variation (Chen et al. 2006, 2010; Gao et al. 2010; Zhang et al. 2008), it would be meaningful to perform an integrated modelling study and understand the simulation effect in such region.

The studies of hydrological processes are essential to having the reasonable estimations for water resources utilization and management. In this study, because of extreme topographical condition, there is a strong spatial heterogeneity in Yarkant River basin. Two popular distributed models SWAT and MIKE SHE are applied to assess model response in arid alpine region. The spatiotemporal distributions of runoff, snowmelt and evapotranspiration form two models are used to explain effects of modules' structure and algorithm on hydrological processes, and reinforce the understanding water cycle processes.

\section{Study Area and Models}

\subsection{Study Area}

Yarkant River (Fig. 1) originated from the north slope of Karakoram Mountains and forms a $2.5 \times 10^{4} \mathrm{~km}^{2}$ oasis along the lower reach below Kaqun station. This oasis is an important agroeconomic zone and cotton production region, and the largest irrigation region in Xinjiang. A region above Kaqun Station (Fig. 1) was selected as study catchment with an area of $50,248 \mathrm{~km}^{2}$, and a main stream length of $585 \mathrm{~km}$. The distribution of precipitation and temperature is strongly uneven in this study region (Kang and He 1991; Yang 1989). The only one internal metrological station named Tashkurgan (Fig. 1) shows the mean annual precipitation of $95 \mathrm{~mm}$ and pan evaporation of $1500 \mathrm{~mm}$ during 2000-2009, and the average temperature was below zero from November to next March.

There are abundant glaciers in this study region of Yarkant River with a total cover area of $5574 \mathrm{~km}^{2}$, the estimated amount of ice storage is $685 \mathrm{~km}^{3}$ (Yang 1989). The melt water provides rich water resources to Yarkant River, with a mean annual discharge of $6.87 \times 10^{10} \mathrm{~m}^{3}$ detected at Kaqun station. Meanwhile, because of seasonal snow and ice melt, temporal distribution of discharge varies seasonally, and proportion of discharge from June to September was approximately $80 \%$ of total discharge.

The study catchment has very complex terrain with extreme variations in elevation gradient: the altitude from $8611 \mathrm{~m}$ down to $1450 \mathrm{~m}$ with an average elevation of $4450 \mathrm{~m}$ and slope of $30.78^{\circ}$. The alpine meadow and snow-ice were dominant land cover types having proportions of 29.63 and $25.89 \%$, respectively. Dystric cambisols, lithic leptosols and haplic chernozems are three prominent soil types and accounts for $36.55,17.46$ and $12.67 \%$ of the basin area, respectively. 
Fig. 1 Location of Yarkant river basin and hydrologic station, meteorological stations and channel network

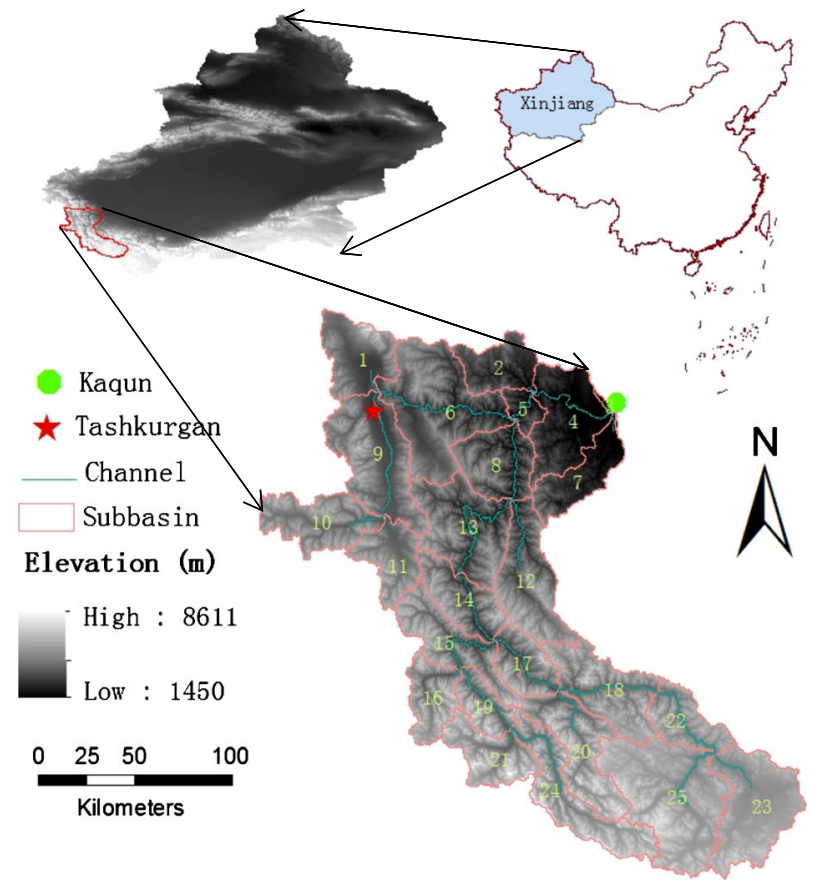

\subsection{Hydrological Models}

Considering the modelling approach, both SWAT and MIKE SHE has their unique features from model structure to governing equations. In SWAT, the catchment is subdivided into subbasins that are connected with the river network; the sub-basin is further subdivided into specific soil/land use/slope characteristic units called Hydrologic Response Units (HRUs). HRUs are the smallest computed unit without any spatial relationship or interaction among them. Semi-empirical Soil Conservation Service (SCS) approach is used to calculate surface flow. After runoff contribution to channels is obtained through water balance control, the variable storage approach or Muskingum methods can be used to compute channel flow. Elevation bands are the important configuration for snowmelt simulation in the SWAT model. Catchment in SWAT can be split into ten elevation bands maximally, within precipitation and temperature adjusted regarding elevation gradient change coefficients.

In MIKE SHE, catchment is split into a number of square grids with explicit geoinformation in horizontal direction. In vertical direction, the vertical variations of soil and hydrogeological characteristics are assigned in number of layers with variable depths. Infiltration is calculated depends on the groundwater conditions and the soil physical attributes which parameters have a clear physical meaning. When water enters unsaturated soil zone, onedimensional Richards equation or Gravity flow equation can be used to calculate the vertical soil interflow. In saturation zone, three-dimensional Darcy equation is employed with an iterative implicit finite difference technique. A dynamic coupling is set between MIKE SHE and MIKE 11 (Thompson et al. 2004) to simulate the dynamic interaction between aquifers 
and stream channels. For the snowmelt module, a threshold temperature is assigned to determine the beginning time of snowfall and snowmelt.

\section{Methodology}

\subsection{Input Data}

Digital Elevation Model (DEM) data with the resolution of $90 \mathrm{~m}$ was used to obtain physical attributes of catchment terrain and river network. The catchment was divided into $25 \mathrm{sub}-$ basins (Fig. 1) in SWAT and simulation resolution of MIKE SHE is $2 \mathrm{~km} \times 2 \mathrm{~km}$. The land use types were determined by the land use data of Global Land Cover Network (GLCN) with resolution of $500 \mathrm{~m} \times 500 \mathrm{~m}$. The remote sensing data images from Moderate Resolution Imaging Spectroradiometer (MODIS) were used to achieve the related parameters such as the leaf area index, root depth, crop coefficient, and growing period of each vegetation type. The properties of the different soil types were based on the data of Harmonized World Soil Database (HWSD).

From China Meteorological Data Sharing Service System, daily data including precipitation, maximum/minimum/mean temperature, wind speed, relative humidity and solar radiation at Tashkurgan station were collected from 2000 to 2009. In SWAT model, precipitation and maximum/minimum temperatures in each elevation band were interpolated from the precipitation lapse rate (PLAPS) and temperature lapse rate (TLAPS). In MIKE SHE model, the catchment was divided into ten regions according the elevation of each grid at 700-meter intervals, every grid in one region shares the same precipitation and temperature time series, which got through the same PLAPS and TLAPS values set as $76 \mathrm{~mm} / \mathrm{km}$ and $-7{ }^{\circ} \mathrm{C} / \mathrm{km}$, respectively, those are based on some investigates about the amount of precipitation and temperature in the different altitude districts (Gao et al. 2010; Jing 2010; Wang et al. 2009).

\subsection{Calibration}

The simulated period was parted warm-up period 2000-2002, calibration period 2003-2007 and verification period 2008-2009. The auto-calibration modules, SWAT-CUP of SWAT and Auto Calibration Tool (ACT) in MIKE SHE package, have been used to calibrate parameters to improve the calibration efficiency. Sequential Uncertainty Fitting (SUFI-2) (Abbaspour et al. 2004) and Shuffled Complex Evolution approach (SCE) (Vrugt et al. 2003) were used in SWAT-CUP and ACT. The simulated daily discharge was calibrated by the objective function according the observation record at Kaqun station. Four statistical coefficients were used to determine the model performances: Nash-Sutcliffe efficiency coefficient (Nush and Sutcliffe 1970) NSE, Pearson correlation coefficient $R$, root-mean-square error RMSE and percentage bias PBIAS. Their formulations are written as:

$$
N S E=1-\frac{\sum_{i=1}^{n}\left(Q_{o b s, i}-Q_{s i m, i}\right)^{2}}{\sum_{i=1}^{n}\left(Q_{o b s, i}-\bar{Q}_{s i m, i}\right)^{2}}
$$




$$
\begin{gathered}
R=\frac{\sum_{i=1}^{n}\left(Q_{o b s, i}-\bar{Q}_{o b s, i}\right)\left(Q_{\text {sim }, i}-\bar{Q}_{\text {sim }, i}\right)}{\sqrt{\sum_{i=1}^{n}\left(Q_{o b s, i}-\bar{Q}_{o b s, i}\right)^{2}} \sqrt{\sum_{i=1}^{n}\left(Q_{\text {sim }, i}-\bar{Q}_{\text {sim }, i}\right)^{2}}} \\
R M S E=\sqrt{\frac{\sum_{i=1}^{n}\left(Q_{\text {sim }, i}-Q_{o b s, i}\right)^{2}}{n}} \\
\text { PBIAS }=\frac{\sum_{i=1}^{n}\left(Q_{\text {sim }, i}-Q_{o b s, i}\right)}{\sum_{i=1}^{n} Q_{o b s, i}}
\end{gathered}
$$

where $Q_{o b s, i}$ and $Q_{\text {sim }, i}$ are the measured and simulated discharges at $i$ th day $\left(\mathrm{m}^{3} / \mathrm{s}\right)$, respectively; $\bar{Q}_{o b s}$ and $\bar{Q}_{\text {sim }}$ are the average measured and simulated discharges in the simulation period $\left(\mathrm{m}^{3} / \mathrm{s}\right)$, respectively; and $n$ is the value of the time steps.

\section{Results and Discussion}

\subsection{Simulation Results}

Figure 2 presents the comparison of simulated and observed discharges at Kaqun station in 2003-2009 at a daily temporal scale. The discharge hydrography curves from SWAT and MIKE SHE caught the overall trend of rising and recession and reflected the temporal characters of stream flow at outlet. According to the evaluation criteria of calibration and verification, both the applications of two models in Yarkant River basin obtained acceptable performances. SWAT obtained slightly better indices (NSE $=0.76$, $\left.R^{2}=0.78, R M S E=144.51, P B A I S=0.22 \%\right)$ than MIKE SHE $\left(N S E=0.71, R^{2}=0.70\right.$, $R M S E=169.88, P B A I S=8.12 \%$ ).

The criteria of discharge calibration are not the overall referential measurements to evaluate the accuracy of hydrologic model application (Vázquez and Feyen 2007), but response of a model to natural hydrologic process can be analysed through the variation

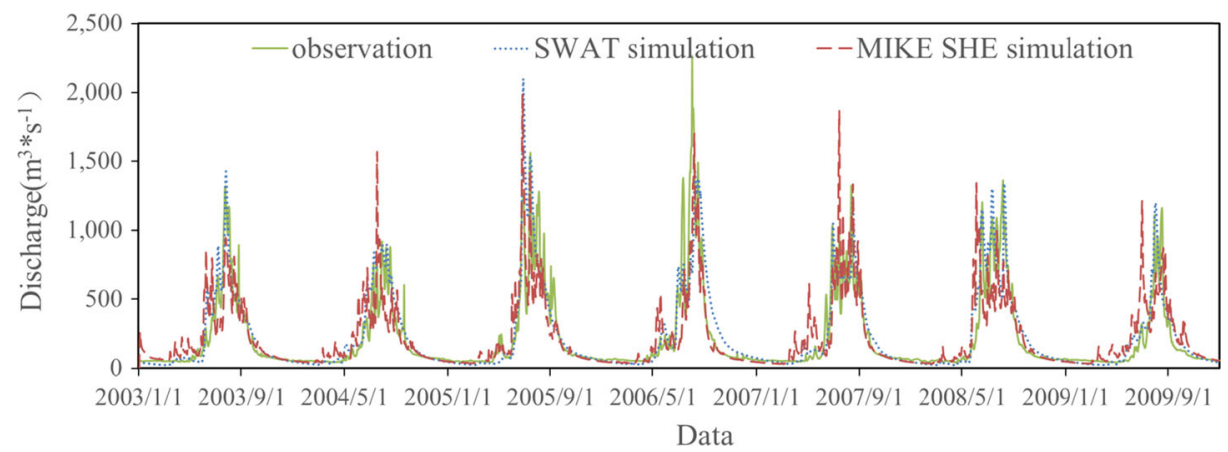

Fig. 2 The observed and simulated daily discharges at Kaqun station 
Table 1 The average annual values of the water components from SWAT and MIKE SHE inYarkant River basin in 2003-2009

\begin{tabular}{lcc}
\hline Element $(\mathrm{mm})$ & SWAT & MIKE SHE \\
\hline Precipitation & 304.3 & 309.6 \\
Snowfall & 237.7 & 231.1 \\
Snowmelt & 145.6 & 152.8 \\
Snow storage & 60.6 & 46.6 \\
Runoff & 160.7 & 146.7 \\
Snow sublimation & 31.4 & 31.7 \\
Canopy interception & 13.72 & 15.6 \\
River/pound water evaporation & 27.38 & 37.1 \\
Soil evaporation /Transpiration & 18.2 & 29.8 \\
\hline
\end{tabular}

of different hydrological elements. Table 1 provides the quantified results of the average annual values of different hydrological components in the whole basin. $\mathrm{ET}_{\mathrm{a}}$ in SWAT and MIKE SHE was furtherly divided into four parts according to their sources: snow sublimation, canopy interception, river/pound water evaporation and soil evaporation/ transpiration. From Table 1, it can be seen there are some notable differences in runoff, snow storage and $\mathrm{ET}_{\mathrm{a}}$ between SWAT and MIKE SHE. It would be worth to exam the differences in more detailed view regarding the different structures and arithmetic.

\subsection{Runoff}

Both in SWAT and MIKE SHE, channel flow was derived from surface runoff and base flow, but the constitutions of base flow are quite distinct in two models. In SWAT, the average annual base flow was $82.6 \mathrm{~mm}$ which is the sum of the groundwater runoff $(16.3 \mathrm{~mm})$ and lateral subsurface runoff $(66.5 \mathrm{~mm})$. While, the base flow in MIKE SHE is groundwater runoff that equals to $31.1 \mathrm{~mm}$. The constitution and distribution of runoff in daily scale is presented in Fig. 3 below. Previous studies reported that the rapid lateral subsurface flow provides a dominant contribution to the storm flow in headwater catchments (Kienzler and Naef 2008; Verseveld et al. 2009; Swarowsky et al. 2012). Especially in alpine area, most of ice-snowmelt water infiltrates into soil and contributes to stream as subsurface lateral flow (Fan et al. 2014) . This feature is described reasonably in SWAT model with subsurface runoff contribution rate of $41.4 \%$, what is anymore, in SWAT, base flow present an obvious seasonality, and little contribution to stream from the November to the following March (Fig. 3).

In MIKE SHE, Richards and Gravity flow equation only take vertical flow into account in unsaturated zone, but when soil moisture is saturated, and head pressure of aquifer water is higher than surface, the infiltrated soil water could flow back to surface, and this part accounted for $39.4 \%$ of total stream runoff in this simulation (close to the subsurface lateral flow of $41.4 \%$ in SWAT). As well as the appropriate soil water recharge to aquifer, MIKE SHE got a persistent and steady contribution to stream in the low water period as base flow (Fig. 3). The proportion of $21.3 \%$ agreed very well with the result of $23 \%$ from Fan et al. (2013), which was obtained through a multiple base flow separate approach. 


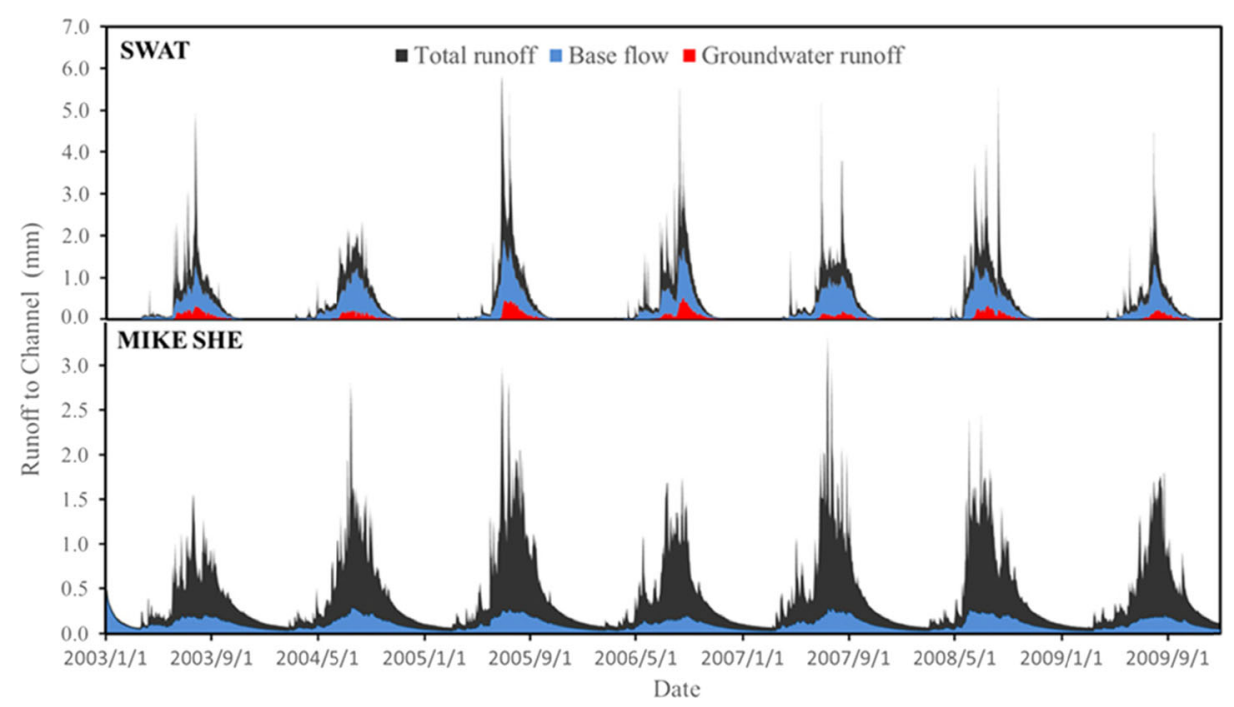

Fig. 3 The daily constitution of the simulation runoff from SWAT and MIKE SHE in Yarkant River basin

\subsection{Snowmelt}

\subsubsection{Temporal Distribution of Snowmelt}

The simulated daily snowmelt in Yarkant River basin from 2003 to 2009 is illustrated in Fig. 4. SWAT resulted in more concentrated snowmelt in temporal distribution; the amount of snowmelt from June to September constituted $76.84 \%$ of the annual snowmelt. While in MIKE SHE, the period of snowmelt is longer and the temporal distribution was more dispersive, and amount of snowmelt from June to September constituted $58.43 \%$.

Degree-day approach is employed in both SWAT and MIKE SHE model to calculate snowmelt. In SWAT, variation of snowmelt factor and snow pack temperature that reflected accumulated temperature of land surface are considered, this is possibly dominant cause for the more concentrated distribution in summer, also the simulation process would be more flexible for catching natural realities rather than only considering air temperature (Zuzel and Cox 1975) in MIKE SHE. Consequently, the temporal distribution of snowmelt in SWAT model matched better with the runoff characteristics of Yarkant River basin, in which the greatest proportion of the water source derives from the melting snow and glaciers, and amount of runoff from June to September accounts for $80 \%$ of the total annual runoff (Chen et al. 2006, 2010).

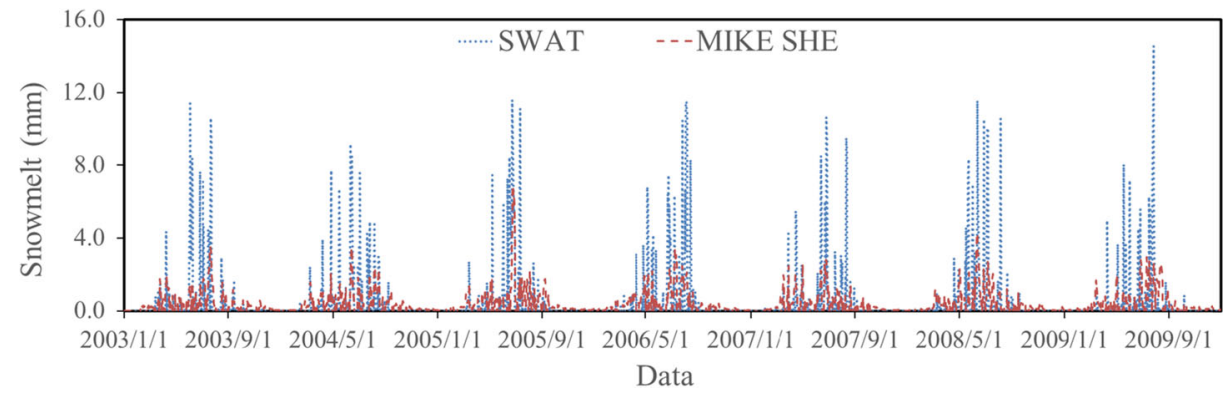

Fig. 4 The simulated daily snowmelt from SWAT and MIKE SHE in Yarkant River basin 


\subsubsection{Spatial Distribution of Snow Storage}

The average annual depth of snow storage from SWAT and MIKE SHE were compared among different elevation bands in Fig. 5, the ones above $7100 \mathrm{~m}$ that have very small area were not demonstrated. From Fig. 5, the consistent tendency of snow storage in different elevation bands from two models can be found. Increasing storage occurs above $5000 \mathrm{~m}$ in both model and the increasing amount was prominent with the higher elevation.

The distribution of elevation bands was rough and cannot illustrate the spatial status of snowpack; hence that, the fine distribution based on model's resolution is shown in Fig. 6. In the first column, the results are from SWAT and are distributed as a sub-basin; in the second column, the results from MIKE SHE are averaged in each sub-basin of SWAT; and in the third column, the results from MIKE SHE are displayed with original grid view. According to first and second column in Fig. 6, two models have a similar tendency for spatial change during the different seasons: till the end of March, almost the entire catchment is covered by snow; snowmelt first occurs around the outlet in April, the snow melt mainly extends to the mountain region approximately $4500 \mathrm{~m}$ in July; and a new increasing storage appears after October; but in the region in which elevation is greater than $5500 \mathrm{~m}$, the snow cover shows a continuously increasing trend throughout the entire year. However, between the first and third column, the spatial distribution of snow cover in MIKE SHE is much more distinct than that in SWAT, and differences of the snow storage depth expressed by the grids of MIKE SHE are much more obvious than by the sub-basins of SWAT.

For the differences of snowpack, the effect of model structure cannot be detached. In SWAT, HRU is the smallest calculated unit, but spatial relation only exists between sub-basins; therefore, an areal depletion curve was introduced when considering the unequal distribution in a sub-basin and makes a uniform spatial distribution of snow storage. As a fully distributed model, in MIKE SHE model, each grid can reflect the actual spatial change of the snow storage in that place, so spatial distribution is more distinct.

\subsection{Evapotranspiration}

Basin on Table 1, the differences of $\mathrm{ET}_{\mathrm{a}}$ between SWAT and MIKE SHE were greatly reflected on river/pound water evaporation and soil evaporation/transpiration, while the other values are

Fig. 5 The snow storage in the different elevation bands from SWAT and MIKE SHE in Yarkant River basin in 2003-2009

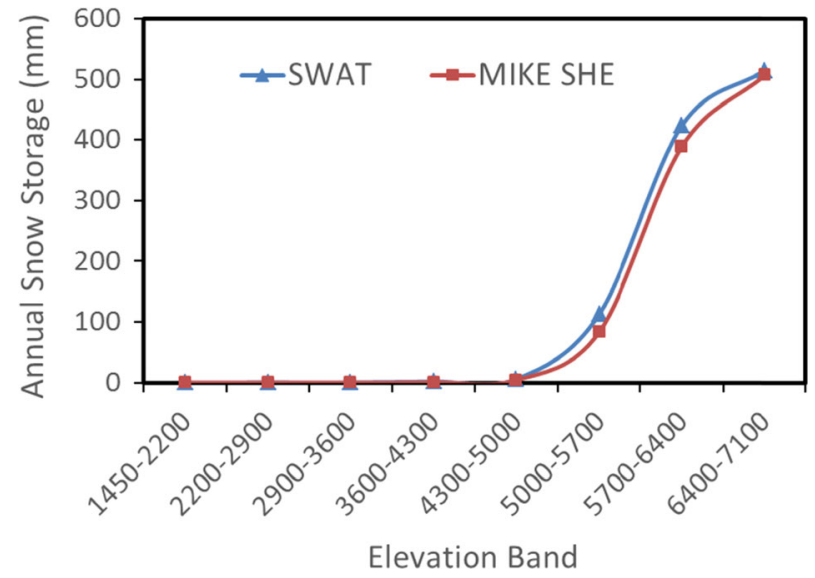




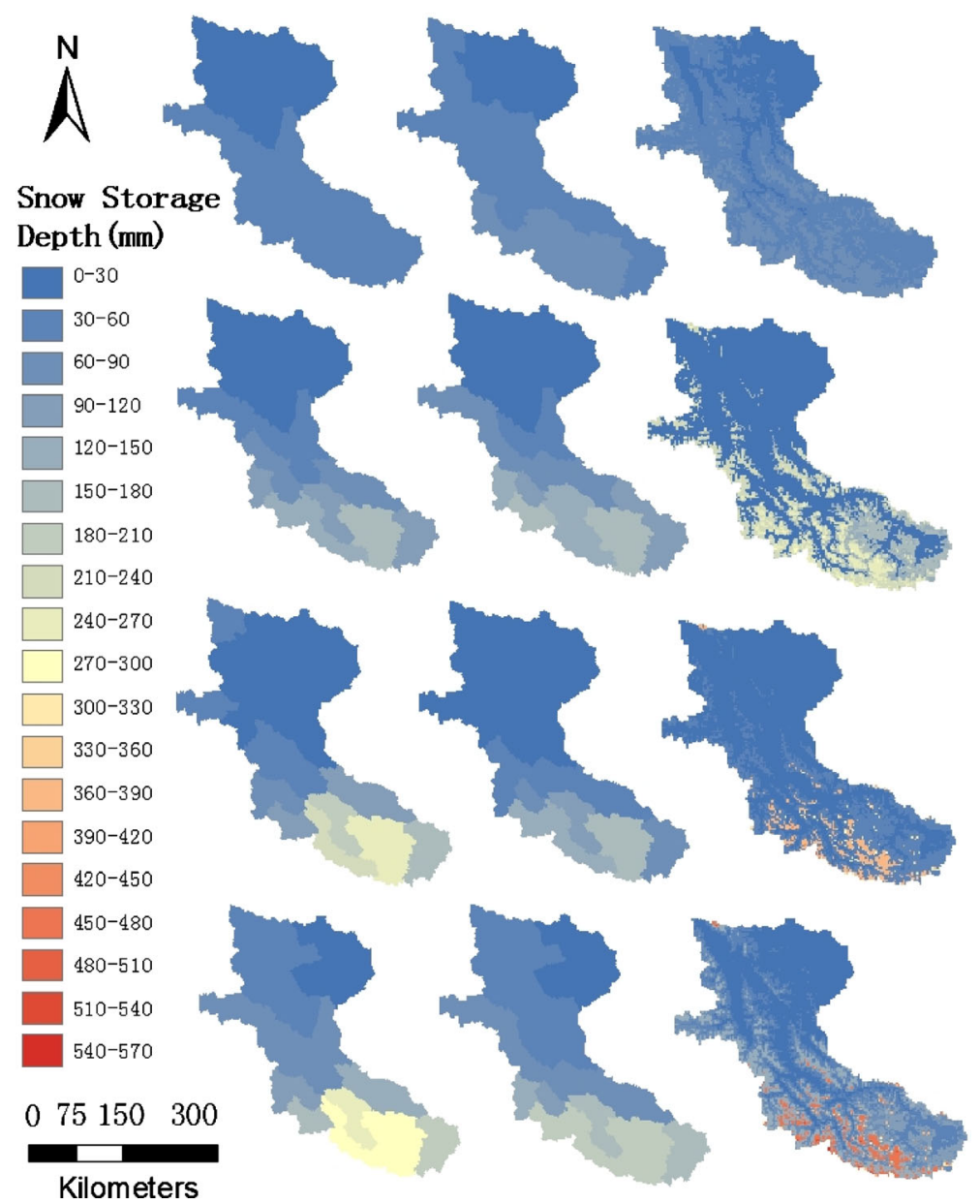

Fig. 6 The simulated snowpack of SWAT ( $1^{\text {st }}$ column), MIKE SHE in sub-basin ( $2^{\text {nd }}$ column) and MIKE SHE $\left(3^{\text {rd }}\right.$ column) in Yarkant River basin on $31^{\text {st }}$ Mar. ( $1^{\text {st }}$ row $), 30^{\text {th }}$ Jun. ( $2^{\text {nd }}$ row $), 30^{\text {th }}$ Sep. $\left(3^{\text {rd }}\right.$ row $)$ and $31^{\text {st }}$ Dec. ( $4^{\text {th }}$ row) 2003

similar. Subsequently, the annual $\mathrm{ET}_{\mathrm{a}}$ in MIKE SHE was $23.5 \mathrm{~mm}$ more than that in SWAT. For the difference in river/pound water evaporation, it is possible that the spatial relationship between calculated units is one cause. In SWAT, HRUs are controlled by water balance independently, but the grids in MIKE SHE are linked by hydrodynamic relation, and the flood detention area is considered, what the result is that larger area of water surface in MIKE SHE model may cause more water evaporation.

The soil evaporation in SWAT is limited by soil moisture content. When soil moisture content is under field capacity, evaporation will be reduced according to their difference. In addition to restrict the amount of soil water evaporation under dry conditions, SWAT also defines a maximum value of soil evaporation as $80 \%$ of the plant available water on a given day. However, in MIKE SHE, without any limitation, all of available water in soil will be used to meet soil evaporation. Therefore, there could be more soil evaporation in MIKE SHE. 


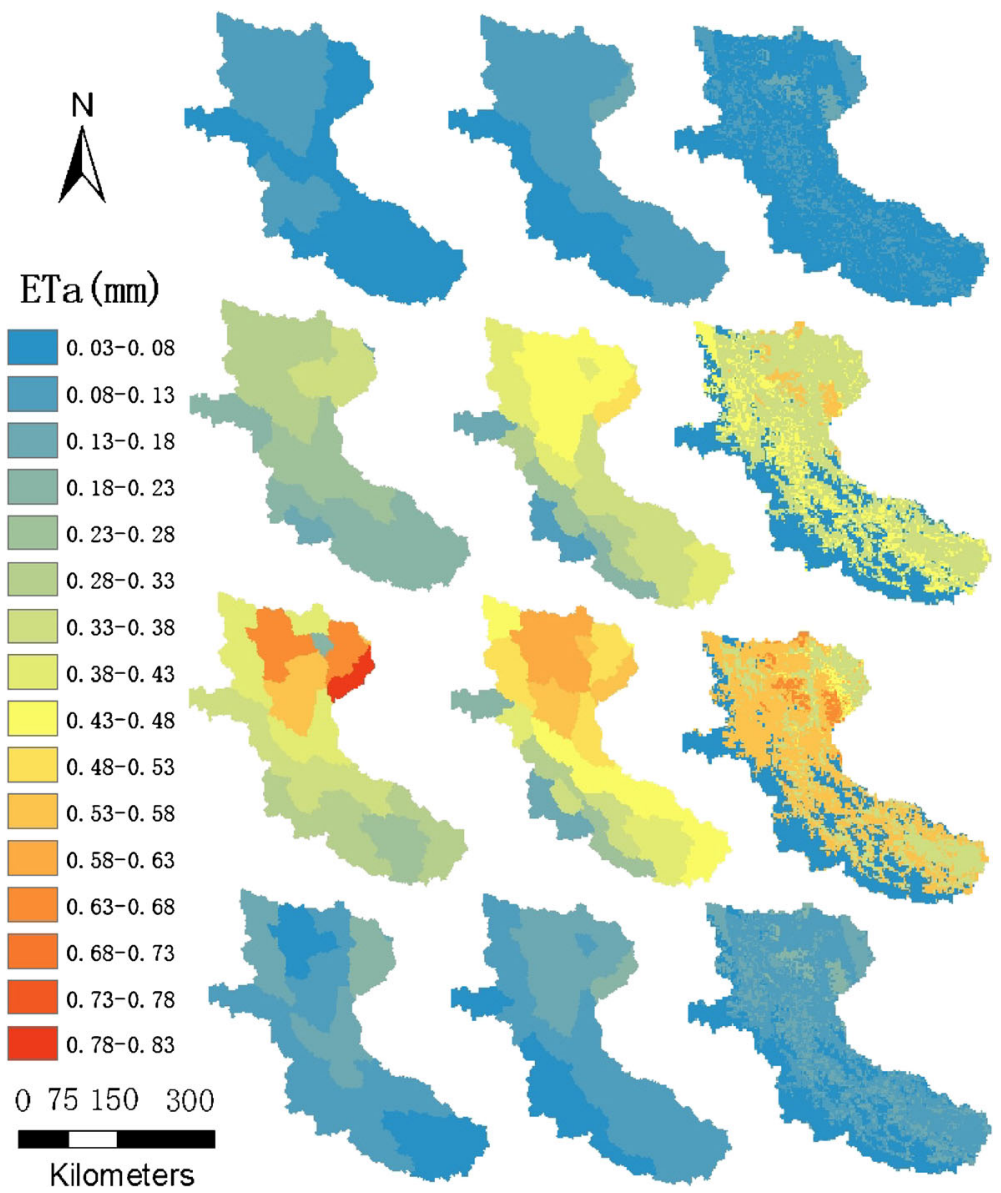

Fig. 7 The daily average evapotranspiration of SWAT ( $1^{\text {st }}$ column), MIKE SHE in sub-basin ( $2^{\text {nd }}$ column) and MIKE SHE ( $3^{\text {rd }}$ column) in Yarkant River from Jan. $\sim$ Mar. (first line), Apr. Jun. (second line), Jul. $\sim$ Sep. (third line), and Oct. $\sim$ Dec (forth line) 2003

From the aspect of spatial distribution based on third column of Fig. 7, the great influence of land use on $\mathrm{ET}_{\mathrm{a}}$ has been clearly demonstrated. Furthermore, comparing the first and second column under the same resolution, the tendency of spatial change is similar in different seasons between SWAT and MIKE SHE: the evapotranspiration around the outlet is much higher than that of the mountain area, because of higher temperature and better plants cover. This spatial difference is much more obvious in the plant grow summer season. However, comparing the first and third column, the semi-distributed SWAT model cannot support the specific information about the spatial distribution.

\section{Summary and Conclusions}

Based on the statistic evaluation indices of discharges calibration on Kaqun station, both SWAT and MIKE SHE got acceptable performances in Yarkant River basin. Because there is no more observations can be used to calibrate models, it would be reasonable to cautiously 
draw the conclusions for model responses to hydrological processes. Therefore, the differences of multiple hydrological components from two models were intercompared based on modules' structures and algorithms, the main consequences include the following aspects.

The phenomenon that most of ice-snowmelt water will infiltrate into the soil and contribute to the stream as subsurface runoff have been described by SWAT, with a contribution proportions of $41.4 \%$. While, MIKE SHE generated a more reasonable base flow with a contribution of $21.3 \%$ also ignoring the soil lateral flow. SWAT obtained a better snowmelt process corresponding to the character of the river flow, but cannot distinctly reflect the spatial features of snowpack that could be detailedly achieved by MIKE SHE. The less ET $_{\mathrm{a}}$ in SWAT has been mainly caused by less water surface area and restrictive setup of soil evaporation function. In comparison, MIKE SHE also provided more information regarding the evapotranspiration being closely related to land use.

From the careful quantifying and reasoning mentioned above, the application of the SWAT and MIKE SHE models in Yarkant River basin can agree with natural observations in some aspects but not in the entire cycle processes. Combined the outputs from two models, an improved understanding of hydrological processes can be presented: SWAT complements the subsurface lateral flow to MIKE SHE which had a better groundwater simulation in this mountainous region; MIKE SHE can supplement the spatial distribution of snowpack and $\mathrm{ET}_{\mathrm{a}}$ for SWAT's output. Moreover, the interpretations of variations between two models stated how the structure and algorithm impact on hydrological processes and provided an inspiring reference to hydrological processes study in other catchments with unique features. In future study on arid and scarcely gauged alpine basin, the joint application of multiple hydrologic models and combined results could be an effective way to control the uncertainties from modules' structure and algorithm, and improving understanding of hydrological processes.

Acknowledgments We gratefully acknowledge the valuable database from SRTM, GLCN, HWSD, Modis and China meteorological data sharing service system. Author is thankful to the assistant of Xinjiang Tarim River Basin Management Bureau. This study is financially supported by the One Thousand Youth Talents Plan of China (Xinjiang Project: 374231001) and Key Program for International Science and Technology Cooperation Projects of China (2010DFA92720-04).

\section{Compliance with Ethical Standards}

\section{Conflict of Interest No conflict of interest}

Open Access This article is distributed under the terms of the Creative Commons Attribution 4.0 International License (http://creativecommons.org/licenses/by/4.0/), which permits unrestricted use, distribution, and reproduction in any medium, provided you give appropriate credit to the original author(s) and the source, provide a link to the Creative Commons license, and indicate if changes were made.

\section{References}

Abbaspour KC, Johnson C, Genuchten V (2004) Estimating uncertain flow and transport parameters using a sequential uncertainty fitting procedure. Vadose Zone J 3(4):1340-1352

Abbott MB, Bathurst JC, Cunge JA, O'Connell PE, Rasmussen J (1986) An introduction to the European Hydrological System-Systeme Hydrologique Europeen, "SHE”, 2: structure of a physically-based, distributed modelling system. J Hydrol 87(1-2):61-77 
Ahl RS, Woods SW, Zuuring HR (2008) Hydrologic calibration and validation of SWAT in a snow-dominated rocky mountain watershed, Montana, USA. J Am Water Resour As 44(6):1411-1430. doi:10.1111/j.17521688.2008.00233.x

Arnold JG, Srinivasan R, Muttiah RS, Williams JR (1998) Large area dyrologic modeling and assessment part 1 model development. J Am Water Resour As 34(1):73-89. doi:10.1111/j.1752-1688.1998.tb05961.x

Barthel R, Reichenau TG, Krimly T, Dabbert S, Schneider K, Mauser W (2012) Integrated modeling of global change impacts on agriculture and groundwater resources. Water Resour Manag 26(7):1929-1951. doi:10. 1007/s11269-012-0001-9

Boorman DB, Sefton CEM (1997) Recognizing the uncertainty in the quantification of the effects of climate change on hydrological response. Clim Chang 35:415-434

Chen Y, Takeuchi K, Xu C, Chen Y, Xu Z (2006) Regional climate change and its effects on river runoff in the Tarim Basin, China. Hydrol Process 20(10):2207-2216. doi:10.1002/hyp.6200

Chen Y, Xu C, Chen Y, Li W, Liu J (2010) Response of glacial-lake outburst floods to climate change in the Yarkant River basin on northern slope of Karakoram Mountains, China. Quatern Int 226(1-2):75-81. doi:10. 1016/j.quaint.2010.01.003

Debele B, Srinivasan R, Gosain AK (2009) Comparison of process-based and temperature-index snowmelt modeling in SWAT. Water Resour Manag 24(6):1065-1088. doi:10.1007/s11269-009-9486-2

El-Nasr AA, Arnold JG, Feyen J, Berlamont J (2005) Modelling the hydrology of a catchment using a distributed and a semi-distributed model. Hydrol Process 19(3):573-587. doi:10.1002/hyp.5610

Fan Y, Chen Y, Liu Y, Li W (2013) Variation of baseflows in the headstreams of the Tarim River Basin during 1960-2007. J Hydrol 487:98-108. doi:10.1016/j.jhydrol.2013.02.037

Fan Y, Chen Y, Li X, Li W, Li Q (2014) Characteristics of water isotopes and ice-snowmelt quantification in the Tizinafu River, north Kunlun Mountains, Central Asia. Quatern Int. doi:10.1016/j.quaint.2014. 05.020

Ferrant S, Oehler F, Durand P, Ruiz L, Salmon MJ, Justes E, Dugast P, Probst A, Probst JL, Sanchez P, José M (2011) Understanding nitrogen transfer dynamics in a small agricultural catchment: comparison of a distributed (TNT2) and a semi distributed (SWAT) modeling approaches. J Hydrol 406(1):1-15. doi:10. 1016/j.jhydrol.2011.05.026

Fontaine TA, Cruickshank TS, Arnold JG, Hotchkiss RH (2002) Development of a snowfall-snowmelt routine for mountainous terrain for the soil water assessment tool(SWAT). J Hydrol 262:209-223

Gao X, Zhang SQ, Ye BS, Jiao CJ (2010) Glacier runoff change in the upper stream of Yarkant River and its impact on river runoff during $1961 \sim 2006$. J Glaciol Geocryol 32(3):445-453

Golmohammadi G, Prasher S, Madani A, Rudra R (2014) Evaluating three hydrological distributed watershed models: MIKE-SHE, APEX, SWAT. Hydrology 1(1):20-39. doi:10.3390/hydrology1010020

Jiang T, Chen YD, Xu CY, Chen X, Chen X, Singh VP (2007) Comparison of hydrological impacts of climate change simulated by six hydrological models in the Dongjiang Basin, South China. J Hydrol 336(3-4):316333. doi:10.1016/j.jhydrol.2007.01.010

Jing S (2010) Estimating vertical distributions of air temperature in high and cold mountain area using sounding temperature. Water Resour Power 28(6):13-17

Kaini P, Artita K, Nicklow JW (2012) Optimizing structural best management practices using SWAT and genetic algorithm to improve water quality goals. Water Resour Manag 26(7):1827-1845. doi:10.1007/s11269-0129989-0

Kang JC, He YQ (1991) Characteristic at boundary face of ice-bedrock on the upper region of Shaksgam Valley, Karakoram. J Glaciol Geocryol 13(4):331-336

Kienzler PM, Naef F (2008) Subsurface storm flow formation at different hillslopes and implications for the old water paradox. Hydrol Process 22(1):104-116. doi:10.1002/hyp.6687

Liu T, Willems P, Pan XL, Bao AM, Chen X, Veroustraete F, Dong QH (2011) Climate change impact on water resource extremes in a headwater region of the Tarim basin in China. Hydrol Earth Syst Sc 8:6593-6637. doi:10.5194/hessd-8-6593-2011

Liu T, Willems P, Feng XW, Li Q, Huang Y, Bao AM, Chen X, Veroustraete F, Dong QH (2012) On the usefulness of remote sensing input data for spatially distributed hydrological modelling: case of the Tarim River basin in China. Hydrol Process 26(3):335-344. doi:10.1002/hyp.8129

Loukas A, Mylopoulos N, Vasiliades L (2007) A modelling system for the evaluation of water resources management strategies in Thessaly, Greece. Water Resour Manag 21:1673-1702. doi:10.1007/s11269006-9120-5

Maurer EP, Brekke LD, Pruitt T (2010) Contrasting lumped and distributed hydrology models for estimating climate change impacts on California Watersheds1. J Am Water Resour As 46(5):1024-1035. doi:10.1111/j. 1752-1688.2010.00473.x

Najafi MR, Moradkhani H, Jung IW (2011) Assessing the uncertainties of hydrologic model selection in climate change impact studies. Hydrol Process 25(18):2814-2826. doi:10.1002/hyp.8043 
Nasr A, Bruen M, Jordan P, Moles R, Kiely G, Byrne P (2007) A comparison of SWAT, HSPF and SHETRAN/ GOPC for modelling phosphorus export from three catchments in Ireland. Water Res 41(5):1065-1073. doi: 10.1016/j.watres.2006.11.026

Nush JE, Sutcliffe JV (1970) River flow forecasting through conceptual models part I - a discussion of principles. J Hydrol 10:282-290

Rahman K, Maringanti C, Beniston M, Widmer F, Abbaspour K, Lehmann A (2012) Streamflow modeling in a highly managed mountainous glacier watershed using SWAT: the upper Rhone river watershed case in Switzerland. Water Resour Manag 27(2):323-339. doi:10.1007/s11269-012-0188-9

Shi P, Chen C, Srinivasan R, Zhang X, Cai T, Fang X, Qu S, Chen X, Li Q (2011) Evaluating the SWAT model for hydrological modeling in the Xixian watershed and a comparison with the XAJ model. Water Resour Manag 25(10):2595-2612. doi:10.1007/s11269-011-9828-8

Smerdon BD, Allen DM, Grasby SE, Berg MA (2009) An approach for predicting groundwater recharge in mountainous watersheds. J Hydrol 365(3-4):156-172. doi:10.1016/j.jhydrol.2008.11.023

Smith MB, Koren V, Zhang Z (2012) Results of the DMIP 2 Oklahoma experiments. J Hydrol 418:17-48

Smith MB, Koren V, Zhang Z (2013) The distributed model intercomparison project-phase 2: experiment design and summary results of the western basin experiments. J Hydrol 507:300-329

Swarowsky A, Dahlgren RA, O'Geen AT (2012) Linking subsurface lateral flowpath activity with streamflow characteristics in a semiarid headwater catchment. Soil Sci Soc Am J 76(2):532. doi:10.2136/sssaj2011.0061

Thampi SG, Raneesh KY, Surya TV (2010) Influence of scale on SWAT model calibration for streamflow in a River Basin in the humid tropics. Water Resour Manag 24(15):4567-4578. doi:10.1007/s11269-010-9676-y

Thompson JR, Sørenson HR, Gavin H, Refsgaard A (2004) Application of the coupled MIKE SHE/MIKE 11 modelling system to a lowland wet grassland in southeast England. J Hydrol 293:151-179. doi:10.1016/j. jhydrol.2004.01.017

Vansteenkiste T, Tavakoli M, Ntegeka V, Willems P, De Smedt F, Batelaan O (2013) Climate change impact on river flows and catchment hydrology: a comparison of two spatially distributed models. Hydrol Process 27(25):3649-3662. doi:10.1002/hyp.9480

Vázquez RF, Feyen J (2007) Assessment of the effects of DEM gridding on the predictions of basin runoff using MIKE SHE and a modelling resolution of 600m. J Hydrol 334(1-2):73-87. doi:10.1016/j.jhydrol.2006.10. 001

Verseveld WJ, McDonnell JJ, Lajtha K (2009) The role of hillslope hydrology in controlling nutrient loss. J Hydrol 367(3-4):177-187. doi:10.1016/j.jhydrol.2008.11.002

Vrugt JA, Gupta HV, Bouten W, Sorooshian S (2003) A shuffled complex evolution metropolis algorithm for optimization and uncertainty assessment of hydrologic model parameters. Water Resour Res 39(8):1-14. doi:10.1029/2002wr001642

Wang D, Liu SJ, Hu LJ, Zhang MX (2009) Monitoring and analyzing the glacier lake outburst floods and glacier variation in the Upper Yarkant River, Karakoram. J Glaciol Geocryol 29(3):808-814

Wood AD (2004) Hydrologic implications of dynamical and statistical approaches to downscaling climate model outputs. Clim Chang 62:189-216

Yang H (1989) Chinese glaciers catalogue: Karakoram area (Yarkant river basin). Science Press, Peking

Zhang XS, Srinivasan R, Debele B, Hao F (2008) Runoff simulation of the headwaters of the yellow river using the SWAT Model with three snowmelt algorithms. J Am Water Resour As 44:48-61

Zuzel JF, Cox LM (1975) Relative importance of meterorological variables in snowmelt. Water Resour Res 11(1):174-177 